\title{
Nitric Oxide as an Activation Agent for Nucleophilic Attack in trans $-\left[\mathrm{Ru}(\mathrm{NO})\left(\mathrm{NH}_{3}\right)_{4}\left\{\mathrm{P}(\mathrm{OEt})_{3}\right\}\right]\left(\mathrm{PF}_{6}\right)_{3}$
}

\author{
Gustavo Metzker, ${ }^{a}$ José C. Toledo Jr., ${ }^{b}$ Francisco C. A. Lima, ${ }^{c}$ Alvicler Magalhães, ${ }^{d}$ \\ Daniel R. Cardoso ${ }^{a}$ and Douglas W. Franco*,a
} ${ }^{a}$ Instituto de Química de São Carlos, Universidade de São Paulo, Av. Trabalhador Sãocarlense 400,
$13560-970$ São Carlos-SP, Brazil

${ }^{b}$ Departamento de Química, Universidade Federal do ABC, Rua Santa Adélia 166, 09210-170 Santo André-SP, Brazil

${ }^{c}$ Centro de Ciências da Natureza, Coordenação de Química, Universidade Estadual do Piauí, Rua João Cabral, 2231, 64002-150 Teresina-PI, Brazil

${ }^{d}$ Instituto de Química, Universidade Estadual de Campinas, Cidade Universitária Zeferino Vaz, 13083-970 Campinas-SP, Brazil

\begin{abstract}
Neste trabalho foi investigado o ataque nucleofílico sofrido no estado sólido pelo complexo trans- $\left[\mathrm{Ru}(\mathrm{NO})\left(\mathrm{NH}_{3}\right)_{4}\left\{\mathrm{P}(\mathrm{OEt})_{3}\right\}\right]\left(\mathrm{PF}_{6}\right)_{3}$, no éster de fósforo coordenado, originando como produto a espécie trans-[Ru(NO) $\left.\left(\mathrm{NH}_{3}\right)_{4}\left\{\mathrm{P}(\mathrm{OH})(\mathrm{OEt})_{2}\right\}\right]\left(\mathrm{PF}_{6}\right)_{3}$. A reação foi monitorada e os produtos caracterizados utilizando ressonância magnética nuclear $\left({ }^{31} \mathrm{P}\left\{{ }^{1} \mathrm{H}\right\} \mathrm{CP}-\mathrm{MAS}\right.$ NMR e $\left.{ }^{31} \mathrm{P}\left\{{ }^{1} \mathrm{H}\right\} \mathrm{NMR}\right)$, espectroscopia no infravermelho (FTIR), ressonância paramagnética eletrônica (EPR), voltametria cíclica (CV), espectroscopia eletrônica (UV-Vis) e análise elementar. De acordo com os dados experimentais e cálculos de mecânica quântica (DFT), a reação ocorre no estado sólido pelo ataque nucleofílico no éster de fósforo coordenado devido à forte polarização no eixo $\mathrm{P}^{\mathrm{III}}-\mathrm{Ru}^{\mathrm{II}}-\mathrm{NO}^{+}$ induzida pela presença do ligante nitrosilo. A reação segue o mecanismo tipo Michaelis-Arbusov para hidrólise de ésteres de fósforo. Em solução ( $\mathrm{pH} 7,0)$, o ataque nucleofílico ocorre nos ligantes $\mathrm{NO}^{+}$e $\mathrm{P}(\mathrm{OEt})_{3}$, gerando como produtos os complexos trans $-\left[\mathrm{Ru}\left(\mathrm{H}_{2} \mathrm{O}\right)\left(\mathrm{NH}_{3}\right)_{4}\left\{\mathrm{P}(\mathrm{OEt})_{3}\right\}\right]^{2+} \mathrm{e}$ trans- $\left[\mathrm{Ru}(\mathrm{NO})\left(\mathrm{H}_{2} \mathrm{O}\right)\left(\mathrm{NH}_{3}\right)_{4}\right]^{3+}$ em proporções comparáveis.
\end{abstract}

The complex trans-[Ru(NO) $\left.\left(\mathrm{NH}_{3}\right)_{4}\left\{\mathrm{P}(\mathrm{OEt})_{3}\right\}\right]\left(\mathrm{PF}_{6}\right)_{3}$ undergoes nucleophilic attack on the

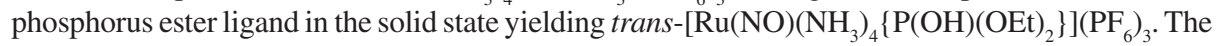
reaction was monitored and the products analyzed using nuclear magnetic resonance spectroscopy $\left({ }^{31} \mathrm{P}\left\{{ }^{1} \mathrm{H}\right\}\right.$ CP-MAS NMR and ${ }^{31} \mathrm{P}\left\{{ }^{1} \mathrm{H}\right\}$ NMR), infrared spectroscopy (FTIR), electron paramagnetic resonance spectroscopy (EPR), cyclic voltammetry (CV), electronic spectroscopy (UV-Vis) and elemental analysis. According to experimental data and quantum mechanical calculations (DFT), the reaction proceeds in the solid state by the nucleophilic attack on the phosphorus ligand, promoted by the strong polarization along the $\mathrm{P}^{\mathrm{III}}-\mathrm{Ru}^{\mathrm{II}}-\mathrm{NO}^{+}$axis induced by the nitrosyl ligand, and takes place following the Michaelis-Arbusov type mechanism for phosphorus ester hydrolysis. In solution, the nucleophilic attack occurs simultaneously at the nitrosyl and triethylphosphite ligands, yielding trans- $\left[\mathrm{Ru}\left(\mathrm{H}_{2} \mathrm{O}\right)\left(\mathrm{NH}_{3}\right)_{4}\left\{\mathrm{P}(\mathrm{OEt})_{3}\right\}\right]^{2+}$ and trans- $\left[\mathrm{Ru}(\mathrm{NO})\left(\mathrm{H}_{2} \mathrm{O}\right)\left(\mathrm{NH}_{3}\right)_{4}\right]^{3+}$ in comparable amounts.

Keywords: nitrosyl, ruthenium, phosphorus ester

\section{Introduction}

The relevance of nitric oxide and therefore of the nitric oxide synthase enzymes (NOS) in biological processes

*e-mail: douglas@iqsc.usp.br is now widely recognized. ${ }^{1-3}$ In the absence of oxygen, i.e., hypoxia situation of living organisms, the NOS enzymes are inhibited. ${ }^{1}$ Ruthenium nitrosyl complexes of the type trans-[Ru(NO) $\left.\left(\mathrm{NH}_{3}\right)_{4}(\mathrm{~L})\right]^{3+}(\mathrm{L}=N$-heterocyclic and triethylphosphite $\left.\mathrm{P}(\mathrm{OEt})_{3}\right)$ are very robust in aqueous solutions, but when activated by one electron reduction, they 
release $\mathrm{NO}^{0}$ at rates that may be controlled depending on the nature of L. ${ }^{4,5}$ Therefore, these compounds would provide $\mathrm{NO}^{0}$ under circumstances where NOS are not operational.

A systematic approach aiming to use ruthenium nitrosyl complexes as NO carriers is being developed. ${ }^{6,7}$ For this, trans $-\left[\mathrm{Ru}(\mathrm{NO})\left(\mathrm{NH}_{3}\right)_{4}\left\{\mathrm{P}(\mathrm{OEt})_{3}\right\}\right]\left(\mathrm{PF}_{6}\right)_{3}$ is found to be interesting since $\mathrm{k}_{-\mathrm{NO}}$ is $0.98 \mathrm{~s}^{-1}$ at $25^{\circ} \mathrm{C}$, the compound is water soluble, its metabolites have very low cytotoxicities, and the $\mathrm{E}_{\mathrm{NO}+\mathrm{NO} 0}^{0}=-0.18 v s$. SCE is accessible to biological reductors such as cysteine, gluthatione and ascorbic acid. ${ }^{8}$ Furthermore, this compound exhibits a quite promising behaviour in biological experiments as tripanomicyde and leishmanicyde agent. ${ }^{9}$

Phosphorus esters are known to be quite reactive. ${ }^{10}$ In acidic solutions, triethylphosphite, $\mathrm{P}(\mathrm{OEt})_{3}$, undergoes acid catalyzed hydrolysis yielding diethylphosphite $\left(\mathrm{P}(\mathrm{OH})(\mathrm{OEt})_{2}\right)$ and diethylphosphonate $\left(\mathrm{P}(\mathrm{H})(\mathrm{O})(\mathrm{OEt})_{2}\right)$ by the Michaelis-Arbusov reaction mechanism. ${ }^{11}$ Furthermore, in the presence of oxidants such as hydrogen peroxide or bromine, the oxidation of $\mathrm{P}^{\mathrm{III}}$ to $\mathrm{P}^{\mathrm{V}}$ is observed to take place easily. The formation of the stable $\mathrm{P}=\mathrm{O}$ bond is considered to be the driving force for this reaction. ${ }^{12}$ However, when coordinated to $\mathrm{Ru}^{\mathrm{II}}, \mathrm{P}(\mathrm{OEt})_{3}$ is stable with respect to oxidation. For example, trans- $\left[\mathrm{Ru}\left(\mathrm{NH}_{3}\right)_{4}\left\{\left(\mathrm{P}(\mathrm{OEt})_{3}\right\}_{2}\right]^{2+}\right.$ is stable in solid state for long periods of storage in a vacuum desiccator and in the absence of light. Also, the complexes trans- $\left[\mathrm{Ru}\left(\mathrm{H}_{2} \mathrm{O}\right)\left(\mathrm{NH}_{3}\right)_{4}\left\{\mathrm{P}(\mathrm{OEt})_{3}\right\}\right]^{2+}$ and trans$\left[\mathrm{Ru}\left(\mathrm{NH}_{3}\right)_{4}\left\{\left(\mathrm{P}(\mathrm{OEt})_{3}\right\}_{2}\right]^{2+}\right.$ are stable in acid aqueous solution even on addition of excess $\mathrm{Br}_{2}$ or $\mathrm{Ce}^{\mathrm{IV}}$, leading only to the metal center oxidation. ${ }^{8}$

Nitrogen monoxide binds strongly to the $\mathrm{Ru}^{\mathrm{II}}$ center and, in this case, the back-bonding in the $\left[\mathrm{Ru}^{\mathrm{II}} \mathrm{NO}^{+}\right]^{3+}$ fragment is so strong that the metal center exhibits properties of $\mathrm{Ru}^{\mathrm{III}} .{ }^{13,14} \mathrm{The} \mathrm{Ru}^{\mathrm{II}}$ center in trans- $\left[\mathrm{Ru}(\mathrm{NO})\left(\mathrm{H}_{2} \mathrm{O}\right)\left(\mathrm{NH}_{3}\right)_{4}\right]^{3+}$ is not oxidized by $\mathrm{Ce}^{\mathrm{IV}}$ or $\mathrm{Br}_{2}$ even in the presence of an excess of these oxidants. ${ }^{15}$ For example, the $\mathrm{pK}_{\mathrm{a}}$ value of the coordinated water molecule in trans- $\left[\mathrm{Ru}(\mathrm{NO})\left(\mathrm{H}_{2} \mathrm{O}\right)\right.$ $\left.\left(\mathrm{NH}_{3}\right)_{4}\right]^{3+}$ is 3.1 , thus being a stronger acid than trans$\left[\mathrm{Ru}\left(\mathrm{H}_{2} \mathrm{O}\right)\left(\mathrm{NH}_{3}\right)_{5}\right]^{2+}, \mathrm{pK}_{\mathrm{a}} 4.5$, by one order of magnitude. ${ }^{15}$ Thus, the presence of the nitrosyl ligand in trans $-[\mathrm{Ru}(\mathrm{NO})$ $\left.\left(\mathrm{NH}_{3}\right)_{4}\left\{\mathrm{P}(\mathrm{OEt})_{3}\right\}\right]\left(\mathrm{PF}_{6}\right)_{3}$ induces not only changes in the metal center but also promotes the activation of the trans positioned phosphorus ester for nucleophilic attack.

Herein the changes induced by nitrosyl in the solid state and solution reactivities of the $\mathrm{P}(\mathrm{OEt})_{3}$ ligand in trans$\left[\mathrm{Ru}(\mathrm{NO})\left(\mathrm{NH}_{3}\right)_{4}\left\{\mathrm{P}(\mathrm{OEt})_{3}\right\}\right]\left(\mathrm{PF}_{6}\right)_{3}$ are described.

\section{Results and Discussion}

Samples of trans- $\left[\mathrm{Ru}(\mathrm{NO})\left(\mathrm{NH}_{3}\right)_{4}\left\{\mathrm{P}(\mathrm{OEt})_{3}\right\}\right]\left(\mathrm{PF}_{6}\right)_{3}$ have shown to undergo gradual degradation in the solid state, even when the complex was stored in a vacuum desiccator under controlled air moisture. Figure 1 illustrates changes in the vibrational spectrum of the complex in solid samples kept for 8 months in such conditions $(\mathrm{p}=0.035$ bar, air moisture $20 \pm 3 \%$ ) and protected from light at room temperature. The dashed line is the spectrum of freshly prepared trans $-\left[\mathrm{Ru}(\mathrm{NO})\left(\mathrm{NH}_{3}\right)_{4}\left\{\mathrm{P}(\mathrm{OEt})_{3}\right\}\right]\left(\mathrm{PF}_{6}\right)_{3}$, which exhibits the characteristic band for coordinated nitrosyl $\left(v\left(\mathrm{NO}^{+}\right)=1915 \mathrm{~cm}^{-1}\right) .{ }^{5}$ The band assigned to $v\left(\mathrm{NO}^{+}\right)$was found to shift to a lower wavenumber $\left(1885 \mathrm{~cm}^{-1}\right)$, indicating changes in the phosphorus ester ligand as a function of time. Concomitantly, changes in the intensity of the band relative to $\delta\left(\mathrm{CH}_{3}\right)$ at $1390 \mathrm{~cm}^{-1}$ (Figure 1, a) were also observed in the aged sample. The area calculated for this band in the degradation product is $35 \%$ smaller than that determined for the starting material. This suggests the loss of an ethyl group $\left(\mathrm{C}_{2} \mathrm{H}_{5}\right)$ from the original complex. Two new bands assigned as $\mathrm{v}(\mathrm{P}-\mathrm{O}-\mathrm{H})^{16}$ are observed to appear at 1140 and $940 \mathrm{~cm}^{-1}$ (Figure 1, b and c), corroborating the nucleophilic attack on the $\mathrm{P}(\mathrm{OEt})_{3}$ ligand. The spectral characteristics suggest that the phosphorus ligand stays coordinated after the hydrolysis process. The $\mathrm{NO}^{+}$ligand was not found to suffer any reaction during the period of time under analysis, as indicated by the FTIR spectra.

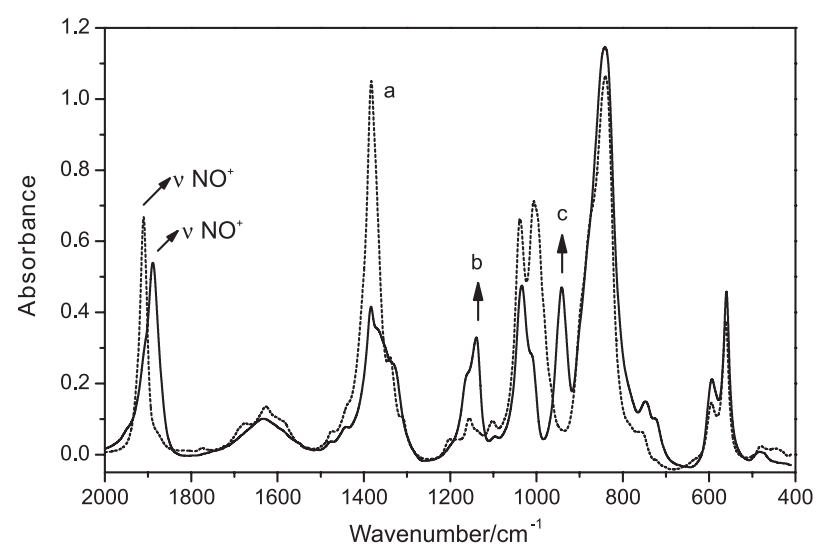

Figure 1. FT-IR spectra of trans- $\left[\mathrm{Ru}(\mathrm{NO})\left(\mathrm{NH}_{3}\right)_{4}\left\{\mathrm{P}(\mathrm{OEt})_{3}\right\}\right]\left(\mathrm{PF}_{6}\right)_{3}$ in the solid state ( $\mathrm{KBr}$ pellets). Dashed line: freshly prepared trans-[Ru(NO) $\left.\left(\mathrm{NH}_{3}\right)_{4}\left\{\mathrm{P}(\mathrm{OEt})_{3}\right\}\right]\left(\mathrm{PF}_{6}\right)$; solid line: complex after 8 months of storage.

To estimate the amount of trans-[Ru(NO) $\left.\left(\mathrm{NH}_{3}\right)_{4}\left\{\mathrm{P}(\mathrm{OEt})_{3}\right\}\right]\left(\mathrm{PF}_{6}\right)_{3}$ that suffered nucleophilic attack, deconvolution analyses of the bands relative to $v\left(\mathrm{NO}^{+}\right)$ at 1915 and $1885 \mathrm{~cm}^{-1}$ were carried out. Results suggest that, after 8 months of storage, approximately $95 \%$ of the original complex was converted into the degradation product. Furthermore, evidence of participation of air moisture in the degradation process was observed. Samples of trans$\left[\mathrm{Ru}(\mathrm{NO})\left(\mathrm{NH}_{3}\right)_{4}\left\{\mathrm{P}(\mathrm{OEt})_{3}\right\}\right]\left(\mathrm{PF}_{6}\right)_{3}$ were also kept under argon in ampoules, where the degradation process was found to 
take place at the beginning and then ceased after 3 months, suggesting that the process is air-moisture dependent. FTIR experiments carried out periodically showed that $20 \%$ of the initial amount of trans-[Ru(NO) $\left.\left(\mathrm{NH}_{3}\right)_{4}\left\{\mathrm{P}(\mathrm{OEt})_{3}\right\}\right]\left(\mathrm{PF}_{6}\right)_{3}$ was converted into the degradation product. For these samples, no additional changes were observed in the FTIR spectra during a period of one year. Also, samples of trans-[Ru(NO) $\left.\left(\mathrm{NH}_{3}\right)_{4}\left\{\mathrm{P}(\mathrm{OEt})_{3}\right\}\right]\left(\mathrm{PF}_{6}\right)_{3}$ stored in Schlenk tubes under dry argon did not undergo any decomposition after three months.

Elemental analysis of the degradated samples of trans- $\left[\mathrm{Ru}(\mathrm{NO})\left(\mathrm{NH}_{3}\right)_{4}\left\{\mathrm{P}(\mathrm{OEt})_{3}\right\}\right]\left(\mathrm{PF}_{6}\right)_{3}$ showed a loss of $35 \%$ in the carbon content, but no changes in the nitrogen content. This is consistent with the loss of one ethyl group $\left(\mathrm{C}_{2} \mathrm{H}_{5}\right)$, suggesting strongly that the $\mathrm{P}(\mathrm{OEt})_{3}$ ligand suffered nucleophilic attack.

Figure 2 shows the UV-Vis spectrum of the degradation product (solid line) obtained after 8 months of storage. The figure clearly depicts bands detected at $242 \mathrm{~nm}$ $\left(\varepsilon=1,429 \mathrm{~L} \mathrm{~mol}^{-1} \mathrm{~cm}^{-1}\right), 312 \mathrm{~nm}\left(\varepsilon=912 \mathrm{~L} \mathrm{~mol}^{-1} \mathrm{~cm}^{-1}\right)$ and $474 \mathrm{~nm}\left(\varepsilon=38 \mathrm{~L} \mathrm{~mol}^{-1} \mathrm{~cm}^{-1}\right)$, indicating that the decomposition product has $\mathrm{NO}^{+}$and a phosphorus ester in the coordination sphere. These absorption coefficient values were calculated considering $95 \%$ of conversion of the original complex into the new one. The electronic spectrum of freshly prepared trans- $\left[\mathrm{Ru}(\mathrm{NO})\left(\mathrm{NH}_{3}\right)_{4}\left\{\mathrm{P}(\mathrm{OEt})_{3}\right\}\right]\left(\mathrm{PF}_{6}\right)_{3}$ (dashed line) has three bands at $260 \mathrm{~nm}\left(\varepsilon=1,291 \mathrm{~L} \mathrm{~mol}^{-1} \mathrm{~cm}^{-1}\right), 316 \mathrm{~nm}$ $\left(\varepsilon=258 \mathrm{~L} \mathrm{~mol}^{-1} \mathrm{~cm}^{-1}\right)$ and $522 \mathrm{~nm}\left(\varepsilon=35 \mathrm{~L} \mathrm{~mol}^{-1} \mathrm{~cm}^{-1}\right)$ attributed to ligand field ( 260 and $316 \mathrm{~nm}$ ) and charge transfer $(522 \mathrm{~nm})$ transitions. ${ }^{8}$ This spectrum and band assignments are consistent with the described for other ruthenium nitrosyl tetraammines. ${ }^{17,18}$ No shift in the bands at 242 and $312 \mathrm{~nm}$

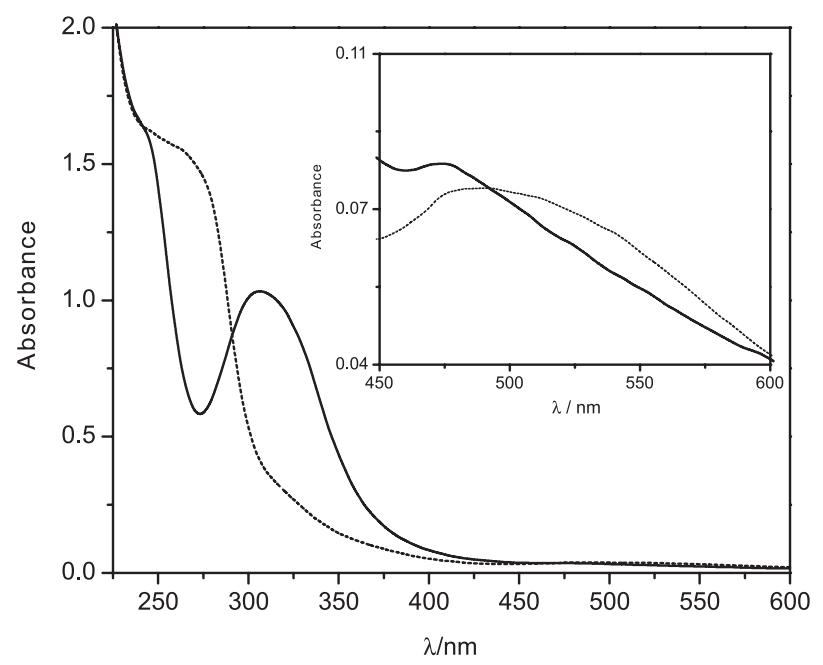

Figure 2. UV-Vis spectra of the degradation product (solid line), $\mathrm{C}_{\mathrm{Ru}}=1.14 \times 10^{-3} \mathrm{~mol} \mathrm{~L}^{-1}$ (insert: $\mathrm{C}_{\mathrm{Ru}}=2.1 \times 10^{-3} \mathrm{~mol} \mathrm{~L}^{-1}$; concentrations considering $95 \%$ of conversion) and trans- $\left[\mathrm{Ru}(\mathrm{NO})\left(\mathrm{NH}_{3}\right)_{4}\left\{\mathrm{P}(\mathrm{OEt})_{3}\right\}\right]$ $\left(\mathrm{PF}_{6}\right)_{3}$ (dashed line), $\mathrm{C}_{\mathrm{Ru}}=1.2 \times 10^{-3} \mathrm{~mol} \mathrm{~L}^{-1}$ (insert: $\mathrm{C}_{\mathrm{Ru}}=2.2 \times 10^{-3} \mathrm{~mol} \mathrm{~L}^{-1}$ ). Insert: region of the charge transfer bands. $\mathrm{T}=25^{\circ} \mathrm{C} ; \mathrm{CF}_{3} \mathrm{COOH} /$ $\mathrm{CF}_{3} \mathrm{COONa}, \mu=0.1 \mathrm{~mol} \mathrm{~L}^{-1} ; \mathrm{pH} 1.0$. in the electronic spectra of the degradation product was observed in acetonitrile, suggesting the predominant ligand field character of the these bands. Due to the microsymmetry similarity exhibited by these two compounds, the electronic absorption bands of the product of nucleophilic attack were tentatively attributed to the same transitions assigned to trans $-\left[\mathrm{Ru}(\mathrm{NO})\left(\mathrm{NH}_{3}\right)_{4}\left\{\mathrm{P}(\mathrm{OEt})_{3}\right\}\right]\left(\mathrm{PF}_{6}\right)_{3}{ }^{8}$

The ${ }^{31} \mathrm{P}\left\{{ }^{1} \mathrm{H}\right\}$ CP-MAS NMR analysis of the decomposition product was also carried out, confirming changes in the coordination sphere of trans- $[\mathrm{Ru}(\mathrm{NO})$ $\left.\left(\mathrm{NH}_{3}\right)_{4}\left\{\mathrm{P}(\mathrm{OEt})_{3}\right\}\right]\left(\mathrm{PF}_{6}\right)_{3}$, as suggested by FTIR and UV-Vis data. After the storage period of 8 months, more than $95 \%$ of the resonance peak recorded at $80 \mathrm{ppm}$ for trans-[Ru(NO) $\left.\left(\mathrm{NH}_{3}\right)_{4}\left\{\mathrm{P}(\mathrm{OEt})_{3}\right\}\right]\left(\mathrm{PF}_{6}\right)_{3}($ Figure 3, top) was observed to disappear, being replaced with a new one at 67 ppm (Figure 3, bottom). According to the literature, ${ }^{8,19}$ this chemical shift region for ${ }^{31} \mathrm{P}$ can be attributed to coordinated $\mathrm{P}$ III , and this indicates that the phosphorus ester remains coordinated after the degradation process. The change in the chemical shift by 13 ppm suggests the formation of a new PIII species coordinated to the $\mathrm{Ru}^{\mathrm{II}}$ center, but with a weaker $\pi$ acidity character than that presented by the $\mathrm{P}(\mathrm{OEt})_{3}$ ligand. This would explain the observed displacement of the peak to a lower chemical shift value as a consequence of the small back-donation between the $\mathrm{Ru}^{\mathrm{II}} 4 \mathrm{~d}_{\pi}$ orbitals and $\mathrm{P}^{\mathrm{III}} 3 \mathrm{~d}_{\pi}$ orbitals. The splitting of the ${ }^{31} \mathrm{P}$ signals in both spectra may be due to polymorphism in the solid state samples. ${ }^{20}$

The ${ }^{31} \mathrm{P}\left\{{ }^{1} \mathrm{H}\right\}$ NMR spectrum of the degradation product in acid aqueous solution $\left(\mathrm{C}_{\mathrm{H}+}=1.0 \times 10^{-1} \mathrm{~mol} \mathrm{~L}^{-1}\right)$ shows only one peak at $67 \mathrm{ppm}$, which is the same chemical shift value found in the ${ }^{31} \mathrm{P}\left\{{ }^{1} \mathrm{H}\right\}$ CP-NMR spectrum. No additional peaks were observed in the NMR spectra for a period of one hour, suggesting that the new complex is stable in this experimental condition.

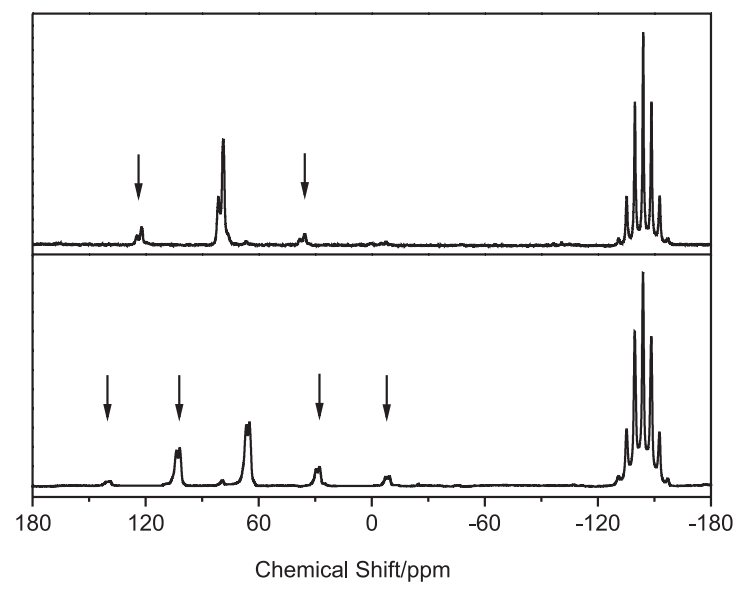

Figure 3. ${ }^{31} \mathrm{P}\left\{{ }^{1} \mathrm{H}\right\} \mathrm{CP}-\mathrm{NMR}$ spectra of trans- $\left[\mathrm{Ru}(\mathrm{NO})\left(\mathrm{NH}_{3}\right)_{4}\left\{\mathrm{P}(\mathrm{OEt})_{3}\right\}\right]$ $\left(\mathrm{PF}_{6}\right)_{3}$ (top) and of the degradation product (bottom). $\mathrm{T}=25^{\circ} \mathrm{C}$. Arrows indicate the side bands in the spectra. 
Cyclic voltammograms of the degradated complex (after 8 months of storage) were obtained in acid aqueous solution ( $\mathrm{pH} 1.0 ; \mu=0.1 \mathrm{~mol} \mathrm{~L}^{-1}$ ) at $25^{\circ} \mathrm{C}$. At first sight, the voltammograms of the degradation product (Figure 4, top) and of the original trans- $\left[\mathrm{Ru}(\mathrm{NO})\left(\mathrm{NH}_{3}\right)_{4}\left\{\mathrm{P}(\mathrm{OEt})_{3}\right\}\right]^{3+}$ (Figure 4, bottom) depict similar qualitative features in the range of +0.70 to $-0.70 \mathrm{~V} v s$. SCE. However, a close comparison of the two species in the voltammogram shows a shift of $200 \mathrm{mV}$ in the half-wave potential attributed to the reversible reduction of the metal center in trans $-\left[\mathrm{Ru}\left(\mathrm{H}_{2} \mathrm{O}\right)\left(\mathrm{NH}_{3}\right)_{4}\left\{\mathrm{P}(\mathrm{OEt})_{3}\right\}\right]^{2+}\left(\mathrm{E}_{1 / 2}^{0} \mathrm{a} 2=0.515 \mathrm{~V}\right)$ and in the degradation product, trans $-\left[\mathrm{Ru}\left(\mathrm{H}_{2} \mathrm{O}\right)\left(\mathrm{NH}_{3}\right)_{4}\{\mathrm{PIII}\}\right]^{2+}$ $\left(\mathrm{E}_{1 / 2}^{0} \mathrm{a} 1=0.315 \mathrm{~V}\right)$. Furthermore, as described previously $\mathrm{y}^{5,8}$ only one reduction wave attributable for the $\mathrm{NO}^{+} / \mathrm{NO}^{0}$

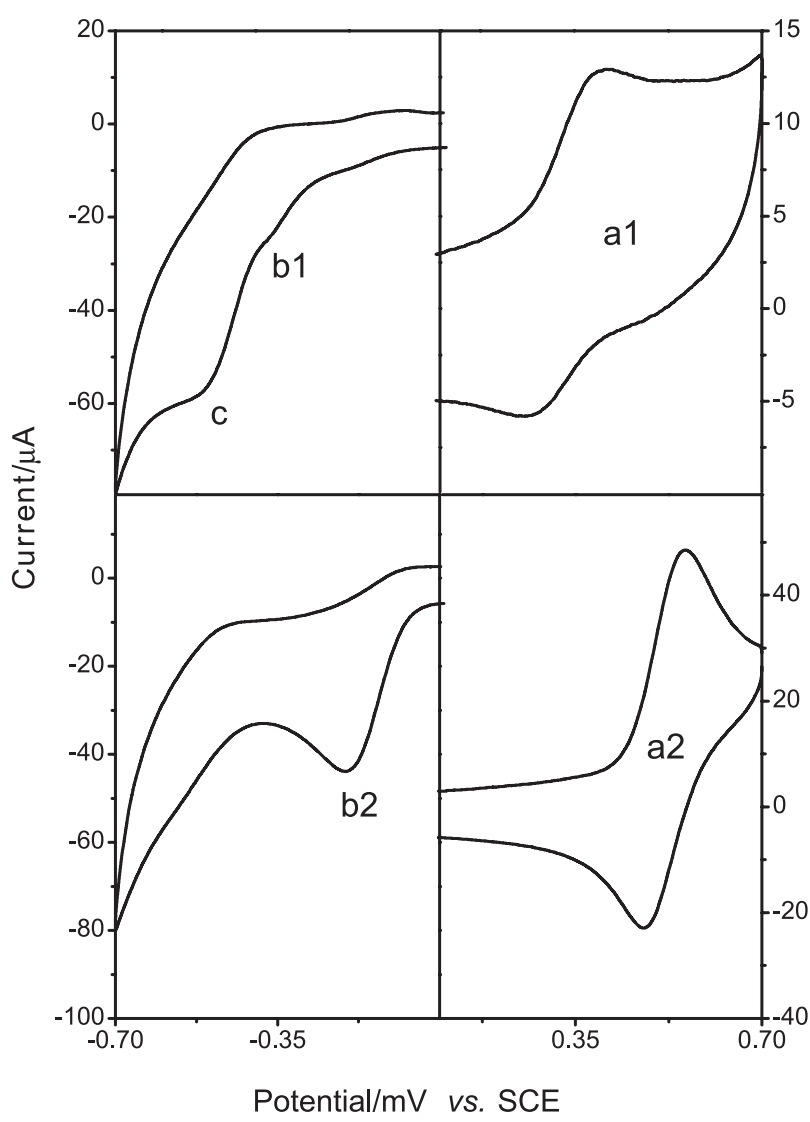

Figure 4. Cyclic voltammograms of trans-[Ru(NO) $\left.\left(\mathrm{NH}_{3}\right)_{4}\left\{\mathrm{P}(\mathrm{OEt})_{3}\right\}\right]$ $\left(\mathrm{PF}_{6}\right)_{3}$ (bottom) and of the degradation product (top) after 8 months of storage. $\mathrm{T}=25^{\circ} \mathrm{C}$; electrolyte $\mathrm{CF}_{3} \mathrm{COOH} / \mathrm{CF}_{3} \mathrm{COONa}, \mu=0.1 \mathrm{~mol} \mathrm{~L}^{-1}$; $\mathrm{pH}=1.0$; scan rate: $100 \mathrm{mV} \mathrm{s}^{-1}$. process is present in the voltammogram of trans- $[\mathrm{Ru}(\mathrm{NO})$ $\left.\left(\mathrm{NH}_{3}\right)_{4}\left\{\mathrm{P}(\mathrm{OEt})_{3}\right\}\right]^{3+}$ at $-0.18 \mathrm{~V}$ (Figure 4 , b2), whereas for the degradation product it is possible to observe two waves: one at $-0.36 \mathrm{~V}$ (b1) and another at $-0.56 \mathrm{~V}$ (c) (Figure 4). From the stand point of the observed peak current intensity, the first wave may be assigned to the reduction process $\mathrm{NO}^{+} / \mathrm{NO}^{0}\left(\mathrm{a} 1 ; \mathrm{E}^{0}=-0.36 \mathrm{~V}\right)$. The shift of the half-wave potential of the $\mathrm{NO}^{+} / \mathrm{NO}^{0}$ couple to more negative values is coherent with the reduced $\pi$ acidity of the phosphorus ester ligand, corroborating the ${ }^{31} \mathrm{P}\left\{{ }^{1} \mathrm{H}\right\}$ CP-NMR and FTIR spectral data.

Until now, we do not have a good explanation for the second peak at $-0.56 \mathrm{~V}$. A more detailed electrochemical investigation is being carried out.

All samples analysed for 8 months were EPR silent, suggesting the presence of only $\mathrm{Ru}^{\mathrm{II}}$ after the degradation process.

Taking in account all data obtained so far, it is likely that the nucleophilic attack on the coordinated phosphorus ester leads, in the solid state, to trans- $\left[\mathrm{Ru}(\mathrm{NO})\left(\mathrm{NH}_{3}\right)_{4}\{\mathrm{P}(\mathrm{OH})\right.$ $\left.\left.(\mathrm{OEt})_{2}\right\}\right]\left(\mathrm{PF}_{6}\right)_{3}$, following the equation:

$$
\begin{aligned}
& \text { trans }-\left[\mathrm{Ru}(\mathrm{NO})\left(\mathrm{NH}_{3}\right)_{4}\left\{\mathrm{P}(\mathrm{OEt})_{3}\right\}\right]^{3+}+\mathrm{H}_{2} \mathrm{O} \frac{\text { Solid State }}{8 \text { months }} \\
& \text { trans }-\left[\mathrm{Ru}(\mathrm{NO})\left(\mathrm{NH}_{3}\right)_{4}\left\{\mathrm{P}(\mathrm{OH})(\mathrm{OEt})_{2}\right\}\right]^{3+}+\text { EtOH }
\end{aligned}
$$

Coordination of $\mathrm{P}(\mathrm{OH})(\mathrm{OEt})_{2}$ to the $\left[\mathrm{Ru}\left(\mathrm{NH}_{3}\right)_{4}\left(\mathrm{H}_{2} \mathrm{O}\right)\right]^{2+}$ moiety was first antecipated by Sernaglia, ${ }^{21}$ who was able to identify in solution the ion trans- $\left[\mathrm{Ru}\left(\mathrm{H}_{2} \mathrm{O}\right)\left(\mathrm{NH}_{3}\right)_{4}\{\mathrm{P}(\mathrm{OH})\right.$ $\left.\left.(\mathrm{OEt})_{2}\right\}\right]^{2+}$. Attempts to isolate trans- $\left[\mathrm{Ru}(\mathrm{NO})\left(\mathrm{NH}_{3}\right)_{4}\{\mathrm{P}(\mathrm{OH})\right.$ $\left.\left.(\mathrm{OEt})_{2}\right\}\right]\left(\mathrm{PF}_{6}\right)_{3}$ from the reaction mixture of trans-[Ru( $\left.\mathrm{H}_{2} \mathrm{O}\right)$ $\left.\left(\mathrm{NH}_{3}\right)_{4}\left\{\mathrm{P}(\mathrm{OH})(\mathrm{OEt})_{2}\right\}\right]^{2+}$ with $\mathrm{NO}_{2}^{-}$in acidic media have been unsuccessful so far. ${ }^{22}$ On the other hand, a recent report describes the synthesis and reactions of the complex $\left[\mathrm{Mo}(\mathrm{CO})_{5}\left\{\mathrm{P}(\mathrm{OH})(\mathrm{OEt})_{2}\right\}\right]$, in which the metal center is also in a $\mathrm{d}^{6}$ low spin configuration. In solution, this complex undergoes nucleophilic attack on the diethylphosphite ligand, yielding $\left[\mathrm{Mo}(\mathrm{CO})_{5}\left\{\mathrm{P}(\mathrm{OH})_{3}\right\}\right]{ }^{23,24}$

Experiments in aqueous media confirm that trans$\left[\mathrm{Ru}(\mathrm{NO})\left(\mathrm{NH}_{3}\right)_{4}\left\{\mathrm{P}(\mathrm{OEt})_{3}\right\}\right]\left(\mathrm{PF}_{6}\right)_{3}$ suffers nucleophilic attack in solution, at $\mathrm{pH} 7.0$, generating two different products: trans-[Ru( $\left.\left.\mathrm{H}_{2} \mathrm{O}\right)\left(\mathrm{NH}_{3}\right)_{4}\left\{\mathrm{P}(\mathrm{OEt})_{3}\right\}\right]^{2+}$ and trans$\left[\mathrm{Ru}(\mathrm{NO})\left(\mathrm{H}_{2} \mathrm{O}\right)\left(\mathrm{NH}_{3}\right)_{4}\right]^{3+}$, following the reaction scheme:

$$
\begin{aligned}
& \text { trans- }\left[\mathrm{Ru}(\mathrm{NO})\left(\mathrm{NH}_{3}\right)_{4}\left\{\mathrm{P}(\mathrm{OEt})_{3}\right\}\right]^{3+}+\mathrm{H}_{2} \mathrm{O} \underset{\mathrm{OH}^{-}}{60 \%} \text { trans- }\left[\mathrm{Ru}\left(\mathrm{NO}_{2}\right)\left(\mathrm{NH}_{3}\right)_{4}\left\{\mathrm{P}(\mathrm{OEt})_{3}\right\}\right]^{2+}+\mathrm{H}_{3} \mathrm{O}^{+} \\
& \text {trans- }\left[\mathrm{Ru}\left(\mathrm{NO}_{2}\right)\left(\mathrm{NH}_{3}\right)_{4}\left\{\mathrm{P}(\mathrm{OEt})_{3}\right\}\right]^{2+}+\mathrm{H}_{2} \mathrm{O} \longrightarrow \text { trans- }\left[\mathrm{Ru}\left(\mathrm{H}_{2} \mathrm{O}\right)\left(\mathrm{NH}_{3}\right)_{4}\left\{\mathrm{P}(\mathrm{OEt})_{3}\right\}\right]^{2+}+\mathrm{NO}_{2}{ }^{-}
\end{aligned}
$$

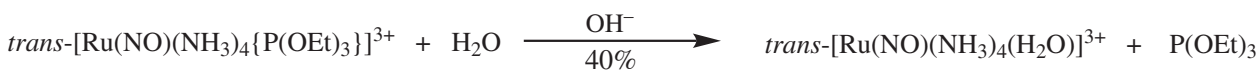

$$
\begin{aligned}
& \mathrm{P}(\mathrm{OEt})_{3} \stackrel{\mathrm{H}_{2} \mathrm{O}}{\longrightarrow} \mathrm{P}(\mathrm{O})(\mathrm{OH})(\mathrm{OEt})_{2}+\mathrm{EtOH}
\end{aligned}
$$


These products were identified through differential pulse voltammetry (DPV) studies (Figure 5), in which the presence of trans- $\left[\mathrm{Ru}\left(\mathrm{H}_{2} \mathrm{O}\right)\left(\mathrm{NH}_{3}\right)_{4}\left\{\mathrm{P}(\mathrm{OEt})_{3}\right\}\right]^{2+}$ and trans $-\left[\mathrm{Ru}(\mathrm{NO})\left(\mathrm{H}_{2} \mathrm{O}\right)\left(\mathrm{NH}_{3}\right)_{4}\right]^{3+}$ was observed at +0.51 (peak c) and $-0.48 \mathrm{~V}$ (peak b) vs. SCE, respectively. Consistently, the FTIR spectrum ${ }^{25}$ from the solution shows $v\left(\mathrm{NO}^{+}\right)=1880 \mathrm{~cm}^{-1}$, indicating the presence of trans$\left[\mathrm{Ru}(\mathrm{NO})\left(\mathrm{H}_{2} \mathrm{O}\right)\left(\mathrm{NH}_{3}\right)_{4}\right]^{3+}$, while the ${ }^{31} \mathrm{P}$ NMR spectrum ( $\delta 148 \mathrm{ppm})$ shows the presence of trans $-\left[\mathrm{Ru}\left(\mathrm{H}_{2} \mathrm{O}\right)\right.$ $\left.\left(\mathrm{NH}_{3}\right)_{4}\left\{\mathrm{P}(\mathrm{OEt})_{3}\right\}\right]^{2+} .{ }^{5}$ According to DPV data, this reaction at $\mathrm{pH} 7.0$ yields $60 \%$ of trans $-\left[\mathrm{Ru}\left(\mathrm{H}_{2} \mathrm{O}\right)\left(\mathrm{NH}_{3}\right)_{4}\left\{\mathrm{P}(\mathrm{OEt})_{3}\right\}\right]^{2+}$ and $40 \%$ of trans-[Ru(NO) $\left.\left(\mathrm{H}_{2} \mathrm{O}\right)\left(\mathrm{NH}_{3}\right)_{4}\right]^{3+}$.

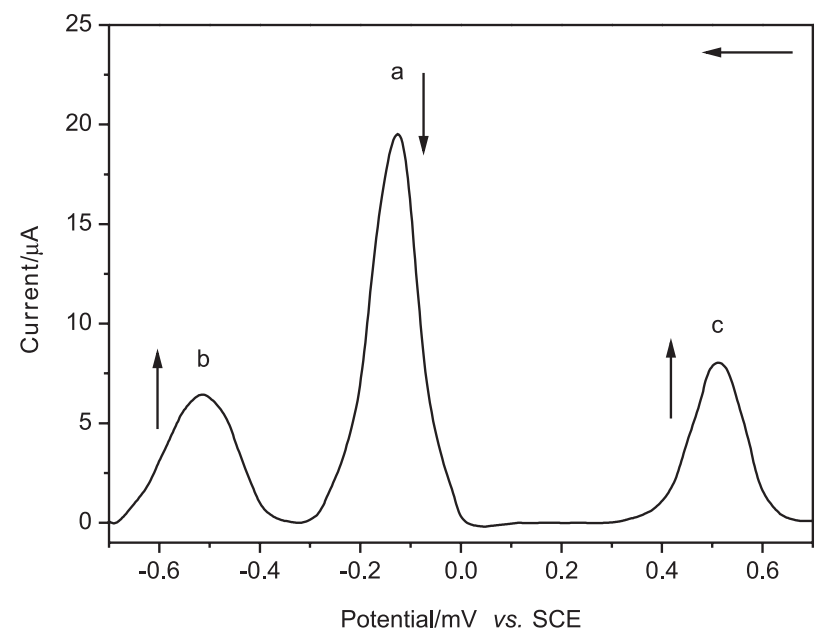

Figure 5. Differential pulse voltammogram (DPV), in aqueous solution, of trans- $\left[\mathrm{Ru}(\mathrm{NO})\left(\mathrm{NH}_{3}\right)_{4}\left\{\mathrm{P}(\mathrm{OEt})_{3}\right\}\right]^{3+}(\mathrm{a}) ;$ trans- $\left[\mathrm{Ru}(\mathrm{NO})\left(\mathrm{H}_{2} \mathrm{O}\right)\left(\mathrm{NH}_{3}\right)_{4}\right]^{3+}(\mathrm{b})$ and trans $-\left[\mathrm{Ru}\left(\mathrm{H}_{2} \mathrm{O}\right)\left(\mathrm{NH}_{3}\right)_{4}\left\{\mathrm{P}(\mathrm{OEt})_{3}\right\}\right]^{2+}(\mathrm{c}) . \mathrm{C}_{\mathrm{Ru}}=5.0 \times 10^{-4} \mathrm{~mol} \mathrm{~L}^{-1}$, $\mathrm{pH} 7.0, \mu=0.1 \mathrm{~mol} \mathrm{~L}^{-1}, \mathrm{~T}=25^{\circ} \mathrm{C}$.

The reaction of phosphorus esters in acid media is well known and recognized to take place following the Michaelis-Arbusov type mechanism, in which the nucleophilic attack occurs at the carbon atom of the $\mathrm{P}(\mathrm{OEt})_{3}$ ligand. The $\mathrm{P}(\mathrm{OEt})_{3}$ coordinated to the ruthenium in trans-[Ru(NO) $\left.\left(\mathrm{NH}_{3}\right)_{4}\left\{\mathrm{P}(\mathrm{OEt})_{3}\right\}\right]^{3+}$ can be activated for nucleophilic attack, with the $\left[\mathrm{Ru}(\mathrm{NO})\left(\mathrm{NH}_{3}\right)_{4}\right]^{3+}$ moiety playing the proton role in the Michaelis-Arbusov mechanism. ${ }^{25}$ In the solid state, water molecules are likely to be the nucleophilic agent, but in solution the behavior is quite different. Only solutions of the ion complex trans- $\left[\mathrm{Ru}(\mathrm{NO})\left(\mathrm{NH}_{3}\right)_{4}\left\{\mathrm{P}(\mathrm{OEt})_{3}\right\}\right]^{3+}$ with $\mathrm{pH}>6.0$ suffered nucleophilic attack, suggesting that in solution $\mathrm{OH}^{-}$is the nucleophilic agent. In this perspective, it is likely that the reactions take place in the solid state and in solution following two different pathways (Scheme 1).

When coordinated to ruthenium in the $\left[\mathrm{Ru}\left(\mathrm{NH}_{3}\right)_{5}\right]^{2+}$ or $\left[\mathrm{Ru}\left(\mathrm{H}_{2} \mathrm{O}\right)\left(\mathrm{NH}_{3}\right)_{4}\right]^{2+}$ complexes, $\mathrm{P}(\mathrm{OEt})_{3}$ is remarkably stabilized towards hydrolysis and thus stable over a wide $\mathrm{pH}$ range. ${ }^{5,8}$ This could be a consequence of an electron density enrichment on the phosphorus and carbon atoms by the strong back-bonding from the filled $\mathrm{Ru}^{\mathrm{II}} 4 \mathrm{~d}_{\pi}$ orbitals to the empty $\mathrm{P}^{\mathrm{III}} 3 \mathrm{~d}_{\pi}$ ligand orbitals..$^{5,8,13,21}$ Under the influence of $\mathrm{NO}^{+}$, the back-bonding is significantly attenuated due to the competition between $\mathrm{P}(\mathrm{OEt})_{3}$ and $\mathrm{NO}^{+}$for the $\mathrm{Ru}^{\mathrm{II}}$ $4 \mathrm{~d}_{\pi}$ electrons. The nearly linear $\mathrm{Ru}^{\mathrm{II}}-\mathrm{NO}^{+}$angle $\left(175^{\circ} .10^{\prime}\right)$ in this complex ${ }^{5,8}$ also offers a favorable symmetry for the overlapping between the empty $\mathrm{p}_{\mathrm{y} \pi^{*}}$ and $\mathrm{p}_{\mathrm{z} \pi^{*}}$ orbitals (in the $\mathrm{NO}^{+}$ligand) and the electron rich $\mathrm{Ru} \mathrm{d} \mathrm{xz}_{\mathrm{x}}$ and $\mathrm{d}_{\mathrm{yz}}$ orbitals. ${ }^{16}$

The changes in the $\mathrm{NO}^{+}$ligand as a consequence of the trans influence of the phosphorus ligand can be envisaged on the plot of $\mathrm{E}^{0}\left(\mathrm{NO}^{+} / \mathrm{NO}^{0}\right)(\mathrm{SCE}) v s . v\left(\mathrm{NO}^{+}\right)\left(\mathrm{cm}^{1}\right)$. As can be observed, the trans- $\left[\mathrm{Ru}(\mathrm{NO})\left(\mathrm{NH}_{3}\right)_{4}\left\{\mathrm{P}(\mathrm{OH})(\mathrm{OEt})_{2}\right\}\right]^{3+}$ ion follows the linear relationship $\left(r^{2}=0.94\right)$ observed $^{5,13}$ for other tetraamines (Figure 6).

The redox potential for the $\mathrm{NO}^{+} / \mathrm{NO}^{0}$ couple and the $v\left(\mathrm{NO}^{+}\right)$in these complexes are both dependent on the $\mathrm{Ru} 4 \mathrm{~d}_{\pi} \rightarrow \mathrm{NO}^{+} \mathrm{p}_{\pi^{*}}$ back-bonding. ${ }^{5,13}$ Based on this, it is possible to infer that the $\pi$ acidity of the phosphite series follows the order:

$\mathrm{P}(\mathrm{OH})_{3}<\mathrm{P}(\mathrm{OH})(\mathrm{OEt})_{2}<\mathrm{P}\left(\mathrm{OPr}^{\mathrm{i}}\right)_{3}<\mathrm{P}(\mathrm{OMe})_{3}<\mathrm{P}(\mathrm{OEt})_{3}<$ $\mathrm{P}(\mathrm{OEtCl})_{3}$

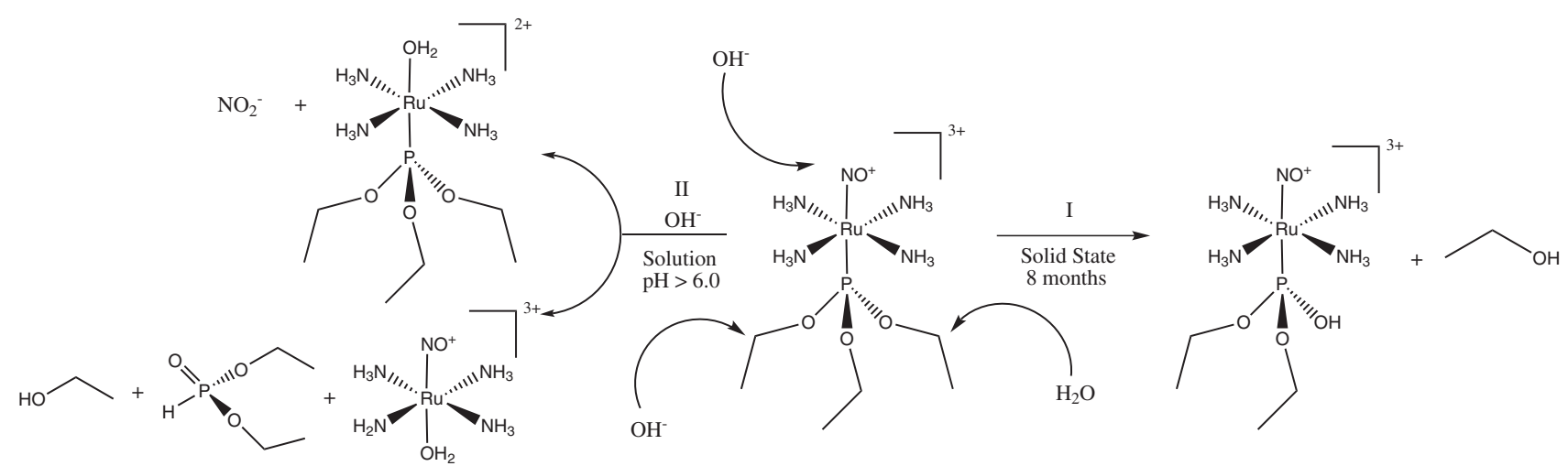

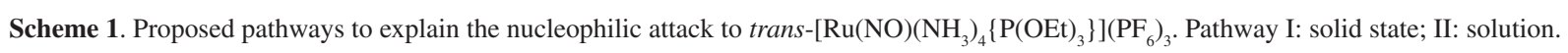




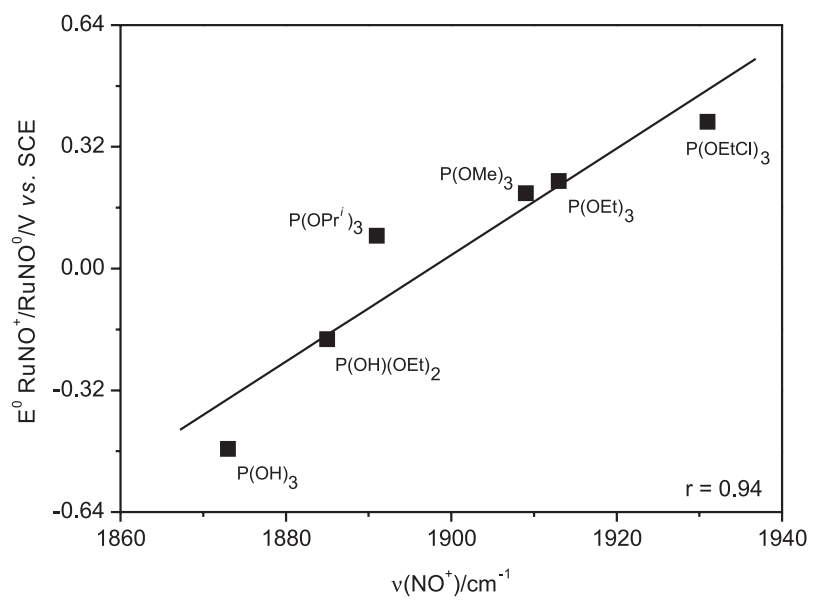

Figure 6. Plot of $\mathrm{E}^{0} \mathrm{Ru}\left(\mathrm{NO}^{+}\right) / \mathrm{Ru}\left(\mathrm{NO}^{0}\right)(\mathrm{V} v$ s. $\mathrm{SCE}) v s . v\left(\mathrm{NO}^{+}\right)\left(\mathrm{cm}^{-1}\right)$ for some ruthenium nitrosyl phosphites.

Theoretical calculations were performed to confirm the hypothesis of formation of trans- $\left[\mathrm{Ru}(\mathrm{NO})\left(\mathrm{NH}_{3}\right)_{4}\{\mathrm{P}(\mathrm{OH})\right.$ $\left.\left.(\mathrm{OEt})_{2}\right\}\right]^{3+}$. The electronic spectrum calculated for trans$\left[\mathrm{Ru}(\mathrm{NO})\left(\mathrm{NH}_{3}\right)_{4}\left\{\mathrm{P}(\mathrm{OH})(\mathrm{OEt})_{2}\right\}\right]\left(\mathrm{PF}_{6}\right)_{3}$ using TD-DFT (time dependent DFT, see Supplementary Information) presented the same shape and band attributions of the spectrum of trans $-\left[\mathrm{Ru}(\mathrm{NO})\left(\mathrm{NH}_{3}\right)_{4}\left\{\mathrm{P}(\mathrm{OEt})_{3}\right\}\right]\left(\mathrm{PF}_{6}\right)_{3}$. The blue shift of the bands in trans $-\left[\mathrm{Ru}(\mathrm{NO})\left(\mathrm{NH}_{3}\right)_{4}\left\{\mathrm{P}(\mathrm{OH})(\mathrm{OEt})_{2}\right\}\right]$ $\left(\mathrm{PF}_{6}\right)_{3}$, as compared to trans-[Ru(NO) $\left.\left(\mathrm{NH}_{3}\right)_{4}\left\{\mathrm{P}(\mathrm{OEt})_{3}\right\}\right]$ $\left(\mathrm{PF}_{6}\right)_{3}$, may be explained by the changes in $\pi$ acidity of the phosphorus ester trans to the nitrosyl ligand. A weaker $\pi$ acid ligand allows a stronger $\mathrm{Ru} 4 \mathrm{~d}_{\pi} \rightarrow \mathrm{NO}^{+} \mathrm{p}_{\pi^{*}}$ backbonding, leading to a larger crystal field splitting between the $4 \mathrm{~d}$ orbitals of the $\mathrm{Ru}{ }^{\mathrm{II}}$ center. From the energy difference of the ligand field bands (Figure 2), it is possible to estimate a stabilization of $c a .7 \mathrm{kcal} \mathrm{mol}^{-1}$ for the ruthenium $4 \mathrm{~d}$ orbitals when $\mathrm{P}(\mathrm{OEt})_{3}$ is replaced with $\mathrm{P}(\mathrm{OH})(\mathrm{OEt})_{2}$.

The electronic density of the phosphorus and carbon atoms of the phosphite ligand is also expected to decrease in the nitrosyl complex. According to DFT calculations performed for the trans $-\left[\mathrm{Ru}(\mathrm{NO})\left(\mathrm{NH}_{3}\right)_{4}\left\{\mathrm{P}(\mathrm{OEt})_{3}\right\}\right]^{3+}$ and trans $-\left[\mathrm{Ru}(\mathrm{NO})\left(\mathrm{NH}_{3}\right)_{4}\left\{\mathrm{P}(\mathrm{OH})(\mathrm{OEt})_{2}\right\}\right]^{3+}$ ions, the composition of the LUMO orbitals is predominantly characteristic of the $\mathrm{NO}^{+}$and $\mathrm{P}(\mathrm{OEt})_{3}$ ligands. From the calculated $\mathrm{NBO}$ charges for trans-[Ru(NO) $\left.\left(\mathrm{NH}_{3}\right)_{4}\left\{\mathrm{P}(\mathrm{OEt})_{3}\right\}\right]^{3+}$ and for the free $\mathrm{P}(\mathrm{OEt})_{3}$ (Table 1), it is possible to infer that, upon coordination to the metal center, remarkable changes occur in the $\mathrm{P}(\mathrm{OEt})_{3}$ ligand, which becomes more electrophilic. According to the NBO charge values, the more positive is the NBO charge value, more susceptible is the atom to nucleophilic attack. ${ }^{26}$

From the NBO data (Table 1) it is possible to infer that four atoms, i.e., the metal center, the nitrogen of the nitrosyl ligand and the phosphorus and carbon atoms of the $\mathrm{CH}_{2}$ groups, are more susceptible to the nucleophilic
Table 1. Calculated NBO charges (in water) for trans-[Ru(NO) $\left.\left(\mathrm{NH}_{3}\right)_{4}\left\{\mathrm{P}(\mathrm{OEt})_{3}\right\}\right]^{3+}$ and for free $\mathrm{P}(\mathrm{OEt})_{3}$

\begin{tabular}{lcc}
\hline Atom & trans $-\left[\mathrm{Ru}(\mathrm{NO})\left(\mathrm{NH}_{3}\right)_{4}\left\{\mathrm{P}(\mathrm{OEt})_{3}\right\}\right]^{3+}$ & $\mathrm{P}(\mathrm{OEt})_{3}$ \\
\hline $\mathrm{Ru}$ & 0.57913 & - \\
$\mathrm{N}$ (ammines) & -1.02148 & - \\
$\mathrm{N}$ (nitrosyl) & 0.30367 & - \\
$\mathrm{O}$ (nytrosil) & 0.04611 & - \\
$\mathrm{P}$ (phosphite) & 1.86304 & 1.62327 \\
$\mathrm{O}$ (phosphite) & -0.90837 & -0.86352 \\
$\mathrm{C}\left(\mathrm{CH}_{2}\right.$ - phosphite $)$ & -0.02532 & -0.10212 \\
$\mathrm{C}\left(\mathrm{CH}_{3}\right.$ - phosphite $)$ & -0.66476 & -0.69486 \\
\hline
\end{tabular}

attack. According to X-ray diffraction data ${ }^{27}$ and quantum mechanical calculations, the metal center and phosphorus atoms, but not the carbon atoms, are expected to exhibit steric hindrance, therefore making the reaction difficult.

The solid state ${ }^{13} \mathrm{C}$ NMR spectra of the nitrosyl complexes containing $\mathrm{P}(\mathrm{OEt})_{3}$ and $\mathrm{P}(\mathrm{OH})(\mathrm{OEt})_{2}$ exhibited chemical shifts of 63 and $70 \mathrm{ppm}$ for the $\mathrm{CH}_{2}$ groups respectively, thus suggesting that the $\mathrm{CH}_{2}$ group in the $\mathrm{P}(\mathrm{OEt})_{3}$ complex is more eletrophilic than in the $\mathrm{P}(\mathrm{OH})(\mathrm{OEt})_{2}$ species, being consequently more susceptible to nucleophilic attack. Corroborating the NBO data on Table 1, the ${ }^{13} \mathrm{C}$ chemical shifts determined for the $\mathrm{CH}_{3}$ groups of the diethyl/triethylphosphite ligands did not show any expressive difference $\left(\delta\left(\mathrm{CH}_{3}\right) 16.0\right.$ and $16.7 \mathrm{ppm}$ respectively). On this perspective, the DFT calculations, together with the ${ }^{13} \mathrm{C}$ NMR data, strongly suggest a nucleophilic attack on the $\mathrm{CH}_{2}$ group of $\mathrm{P}(\mathrm{OEt})_{3}$, following the Michaelis-Arbusov type mechanism of phosphorous ester hydrolysis and leading to $\mathrm{P}(\mathrm{OH})(\mathrm{OEt})_{2}$.

\section{Experimental}

All reagents were used as purchased from Aldrich and Merck. $\mathrm{P}(\mathrm{OEt})_{3}$ was purified as described before. ${ }^{8}$ Solvents, purchased from Mallinckrodt Baker and Merck, were purified following literature procedures. ${ }^{29}$ Five samples of the trans- $\left[\mathrm{Ru}(\mathrm{NO})\left(\mathrm{NH}_{3}\right)_{4}\left\{\mathrm{P}(\mathrm{OEt})_{3}\right\}\right]\left(\mathrm{PF}_{6}\right)_{3}$ complex were periodically analysed by spectroscopic techniques during a period of 8 months. Samples were stored in a vacuum desiccator ( $p=0.035$ bar), in which air moisture was controlled with a drying agent $\left(\mathrm{CaCl}_{2} \cdot \mathrm{H}_{2} \mathrm{O}\right.$, air moisture $20 \pm 3 \%) .{ }^{29}$ Air moisture was continuosly measured using a hygrometer (Barigo, Vilingen-Schwenningen, Germany) and the samples homogenized every 15 days to avoid only superficial degradation. All manipulations of air sensitive compounds were carried out as described in literature, ${ }^{30}$ using serum caps, teflon tubes and glass 
syringes. The complex trans-[Ru(NO) $\left.\left(\mathrm{NH}_{3}\right)_{4}\left\{\mathrm{P}(\mathrm{OEt})_{3}\right\}\right]$ $\left(\mathrm{PF}_{6}\right)_{3}$ was synthesized as described in the literature. ${ }^{5} \mathrm{UV}-$ Vis measurements were performed on a Hitachi U-3501 spectrophotometer using a $1.0 \mathrm{~cm}$ path length quartz cell. Degassed solutions of the degradation product were transferred into quartz cells using teflon tubes. The spectra were recorded from 225 to $600 \mathrm{~nm}$. FTIR spectra were recorded using a Bomem MB-102 series spectrometer, using $\mathrm{KBr}$ pellets, in the region of $2000-400 \mathrm{~cm}^{-1}$. Elemental analysis was performed on an EA 1110 CHNS-O Carlo Erba Instrument. ${ }^{31} \mathrm{P}\left\{{ }^{1} \mathrm{H}\right\}$ CP-MAS NMR measurements were carried out with a Varian Inova $400 \mathrm{MHz}$ spectrometer using fine powdered samples packed into a zirconia $\mathrm{CP}$ rotor. The counter ion $\mathrm{PF}_{6}^{-}$(from $\mathrm{NH}_{4}\left(\mathrm{PF}_{6}\right), \delta^{31} \mathrm{P}=$ $-144 \mathrm{ppm}$ ) was used as reference. EPR spectra were recorded on a Bruker ESP 300E X-band spectrometer at $77 \mathrm{~K}$. DPPH• $(\mathrm{g}=2.0037)$ was used as the field calibrant. Electrochemical measurements (CV and DPV) were performed on an EG\&G PAR model 264A equipment, using a glass carbon electrode as a working electrode, a saturated calomel electrode (SCE) as reference and a platinum plate as auxiliary electrode. Solutions of $\mathrm{CF}_{3} \mathrm{COOH} / \mathrm{CF}_{3} \mathrm{COONa}$ $\left(\mu=0.1 \mathrm{~mol} \mathrm{~L}^{-1}\right)$ were used as electrolyte.

DFT calculations for trans-[Ru(NO) $\left.\left(\mathrm{NH}_{3}\right)_{4}\left\{\mathrm{P}(\mathrm{OEt})_{3}\right\}\right]^{3+}$ and trans $-\left[\mathrm{Ru}(\mathrm{NO})\left(\mathrm{NH}_{3}\right)_{4}\left\{\mathrm{P}(\mathrm{OH})(\mathrm{OEt})_{2}\right\}\right]^{3+}$ were performed with the Gaussian 03 package..$^{31}$ Optimized molecular geometries were calculated using the hybrid B3LYP exchange-correlation functional with the GDIIS algorithm, ${ }^{32,33}$ and tight self-consistent field convergence criteria were used for calculations. Solvent effects were evaluated using the Polarizable Continuum Model (PCM). ${ }^{34}$ Single-point calculations with the B3LYP and the standard 6-311+G* basis sets for $\mathrm{H}, \mathrm{C}, \mathrm{N}, \mathrm{P}$ and $\mathrm{O}$, and the LANL2DZ basis set for Ru were performed. A dielectric constant of $\varepsilon=78.39$ was used for the complexes in water. Natural atomic charges ${ }^{35}$ from natural population analysis (NPA) were obtained with the NBO 3.0 program as implemented in the Gaussian 03 software. All the fully optimized geometries were characterized by vibrational frequency calculations, which showed only real frequencies. Zero-point vibrational energies were estimated based on the B3LYP frequency calculation (unscaled) using the same basis set as for geometry optimization.

\section{Conclusions}

The data presented here strongly suggest that, in solid state, a nucleophilic attack at the $\mathrm{CH}_{2}$ group of $\mathrm{P}(\mathrm{OEt})_{3}$ coordinated to the $\mathrm{Ru}^{\mathrm{II}}$ center in trans- $[\mathrm{Ru}(\mathrm{NO})$ $\left.\left(\mathrm{NH}_{3}\right)_{4}\left\{\mathrm{P}(\mathrm{OEt})_{3}\right\}\right]\left(\mathrm{PF}_{6}\right)_{3}$ occurs, leading to the formation of

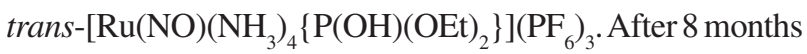
of storage, the conversion was found to be higher than $95 \%$ and the diethylphosphite complex was stable for a period of at least one year. The degradation process was followed with five independent samples and shown to be reproducible. The nucleophilic attack follows the Michaelis-Arbusov type-reaction mechanism. In solution, the nucleophilic attack occurs on the $\mathrm{NO}^{+}$and $\mathrm{P}(\mathrm{OEt})_{3}$ ligands competitively, yielding the trans- $\left[\mathrm{Ru}\left(\mathrm{H}_{2} \mathrm{O}\right)\left(\mathrm{NH}_{3}\right)_{4}\left\{\mathrm{P}(\mathrm{OEt})_{3}\right\}\right]^{2+}$ and trans- $\left[\mathrm{Ru}(\mathrm{NO})\left(\mathrm{H}_{2} \mathrm{O}\right)\left(\mathrm{NH}_{3}\right)_{4}\right]^{3+}$ complex ions. The presence of the nitrosyl on the Ru coordination sphere appears to be the driving force for the nucleophilic attack, since no reaction was observed in the same experimetal conditions for the synthetic precursors of the nitrosyl complex. The strong $\pi$ electron polarization generated by $\mathrm{NO}^{+}$may be useful as catalysis strategy to activate molecules for nucleophilic attack in biological pathways where NO is involved.

\section{Supplementary Information}

Supplementary data are available free of charge at http://jbcs.sbq.org.br, as a pdf file.

\section{Acknowledgments}

The authors acknowledge the Brazilian funding agencies FAPESP (Proc. 05/53266-4 and 06/05877-4), CNPq and CAPES for financial support. Prof. Leif H. Skibsted (University of Copenhagen) is acknowledged for reading the manuscript and Prof. Eduardo R. Azevedo (IFSC/USP) for carrying out the ${ }^{31} \mathrm{P}\left\{{ }^{1} \mathrm{H}\right\}$ CP-MAS NMR experiments.

\section{References}

1. Lundberg, J. O.; Weitzberg, E.; Gladwin, M. T.; Nat. Rev. Drug Discovery 2008, 7, 156.

2. Li, H.; Igarashi, J.; Jamal, J.; Yang, W.; Poulos, T. L.; J. Biol. Inorg. Chem. 2006, 11, 753.

3. Cullota, E.; Koshland, J. D. E.; Science 1992, 258, 1862.

4. Toledo, J. C.; Silva, H. A. S.; Scarpellini, M.; Mori, V.; Camargo, A. J.; Bertotti, M.; Franco, D. W.; Eur. J. Inorg. Chem. 2004, 9, 1879.

5. Tfouni, E.; Krieger, M.; McGarvey, B. R.; Franco, D. W.; Coord. Chem. Rev. 2003, 236, 57.

6. Clarke, M. J.; Coord. Chem. Rev. 2003, 236, 209.

7. McCleverty, J. A.; Chem. Rev. 2004, 104, 403.

8. Franco, D. W.; Taube, H.; Inorg. Chem. 1978, 17, 571; Lopes, L. G. F.; Castellano, E. E.; Ferreira, A. G.; Davanzo, C. U.; Clarke, M. J.; Franco, D. W.; Inorg. Chim. Acta 2005, 358, 2883.

9. Silva, J. J. N.; Osakabe, A. L.; Pavanelli, W. R.; Silva, J. S.; Franco, D. W.; Br. J. Pharmacol. 2007, 152, 112. 
10. Ishmaeva, E. A.; Popova, E. V.; Mironov, V. F.; Aminova, R. M.; Vereshchagina, Y. A.; Galkin, V. I.; Moeller, K.; Schmutzler, R.; Russ. J. Org. Chem. 2004, 40, 1076; Doak, G. O.; Freedman, L. D.; Chem. Rev. 1961, 61, 31.

11. Corbridge D. C. E.; Phosphorus: An Outline of its Chemistry, Biochemistry and Technology, $4^{\text {th }}$ ed., Elsevier: Amsterdam, 1990.

12. Kirby, A. J.; Warren, S. G.; The Organic Chemistry of Phosphorus, $1^{\text {st }}$ ed., Elsevier: New York, 1967.

13. Toledo, J. C.; Lima-Neto, B. S.; Franco, D. W.; Coord. Chem. Rev. 2005, 249, 419.

14. Caramori, G. F.; Frenking, G.; Organometalics 2007, 26, 5815.

15. Bezerra, C. W. B.; Silva, S. C.; Gambardella, M. T. P.; Santos, R. H. A.; Plicas L. M. A.; Tfouni, E.; Franco, D. W.; Inorg. Chem. 1999, 8, 5660.

16. Nakamoto, K.; Infrared and Raman Spectra of Inorganic and Coordination Compounds, $4^{\text {th }}$ ed., John Wiley \& Sons: New York, 1986; Socrates, G.; Infrared and Raman Characteristic Group Frequencies, $3^{\text {rd }}$ ed., John Wiley \& Sons: New York, 2001.

17. Schreiner, A. F.; Lin, S. W.; Hausser, P. J.; Hopcus, E. A.; Hamm, D. J.; Gunter, J. D.; Inorg. Chem. 1972, 11, 880.

18. Gorelsky, S. I.; Silva, S. C.; Lever, A. B. P.; Franco, D. W.; Inorg. Chim. Acta 2000, 300, 698.

19. Verdake, J. G.; Quin, L. D.; Phophorus-31 NMR Spectroscopy on Stereochemical Analysis, VCH Paublishers: Deerfield Beach, 1987.

20. Aguiar, M. R. M. P.; Gemal, A. L.; Gil, R. A. S. S.; Quim. Nova 1999, 22, 553; Penner, G. H.; Wasylishen, R. E.; Can. J. Chem. 1989, 67, 1909; Moynihan, H. A.; O’Hare, I. P.; Int. J. Pharmam. 2002, 247, 179.

21. Sernaglia, R. L.; Franco, D. W.; Inorg. Chem. 1989, $28,3485$.

22. Truzzi, D. R.; Franco, D. W.; Abstracts of the XIV Brazilian Meeting in Inorganic Chemistry, Foz de Iguaçu, Brazil, 2008.

23. Xi, C.; Liu, Y.; Lai, C.; Zhou, L.; Inorg. Chem. Commun. 2004, 7, 1202.

24. Han, L. B.; Tanaka, M.; J. Am. Chem. Soc. 1996, 118, 1571.

25. Brill, T. E.; Landon, S. J.; Chem. Rev. 1984, 84, 577; Bezerra, C. W. B.; Silva, S. C.; Gambardella, M. T. P.; Santos, R. H. A.; Plicas, M. L.; Tfouni, E.; Franco, D. W.; Inorg. Chem. 1999, 38,5660 .
26. Koleva, G.; Galabov, B.; Wu, J. I.; Schaefer, H. F.; Schleyer, P. R.; J. Am. Chem. Soc. 2009, 131, 14772.

27. Mazzetto, S. E.; Gambardella, M. T. P.; Santos, R. H. A.; Lopes, L. G. F.; Franco, D. W.; Polyhedron 1999, 18, 979.

28. Perrin, D. D.; Armarego, W. L. F.; Purification of Laboratory Chemicals, $3^{\text {rd }}$ ed., Pergamon Press: New York, 1983.

29. Kolthoff, I. M.; Quantitative Chemical Analysis, $4^{\text {th }}$ ed., Macmillan: New York, 1969.

30. Shriver, D. F.; Drezdzon M. A.; The Manipulation of AirSensitive Compounds, $2^{\text {nd }}$ ed., Wiley: New York, 1986.

31. Frisch, M. J.; Trucks, G. W.; Schlegel, H. B.; Scuseria, G. E.; Robb, M. A.; Cheeseman, J. R.; Montgomery Jr., J. A.; Vreven, T.; Kudin, K. N.; Burant, J. C.; Millam, J. M.; Iyengar, S. S.; Tomasi, J.; Barone, V.; Mennucci, B.; Cossi, M.; Scalmani, G.; Rega, N.; Petersson, G. A.; Nakatsuji, H.; Hada, M.; Ehara, M.; Toyota, K.; Fukuda, R.; Hasegawa, J.; Ishida, M.; Nakajima, T.; Honda, Y.; Kitao, O.; Nakai, H.; Klene, M.; Li, X.; Knox, J. E.; Hratchian, H. P.; Cross, J. B.; Bakken, V.; Adamo, C.; Jaramillo, J.; Gomperts, R.; Stratmann, R. E.; Yazyev, O.; Austin, A. J.; Cammi, R.; Pomelli, C.; Ochterski, J. W.; Ayala, P. Y.; Morokuma, K.; Voth, G. A.; Salvador, P.; Dannenberg, J. J.; Zakrzewski, V. G.; Dapprich, S.; Daniels, A. D.; Strain, M. C.; Farkas, O.; Malick, D. K.; Rabuck, A. D.; Raghavachari, K.; Foresman, J. B.; Ortiz, J. V.; Cui, Q.; Baboul, A. G.; Clifford, S.; Cioslowski, J.; Stefanov, B. B.; Liu, G.; Liashenko, A.; Piskorz, P.; Komaromi, I.; Martin, R. L.; Fox, D. J.; Keith, T.; Al-Laham, M. A.; Peng, C. Y.; Nanayakkara, A.; Challacombe, M.; Gill, P. M. W.; Johnson, B.; Chen, W.; Wong, M. W.; Gonzalez, C.; Pople, J. A.; Gaussian 03 Revision C.02; Wallingford, 2004.

32. Becke, A. D.; J. Chem. Phys. 1993, 98, 5648.

33. Farkas, O.; Schlegel, H. B.; J. Chem. Phys. 1999, 111, 10806.

34. Cances, E.; Mennucci, B.; Tomasi, J.; J. Chem. Phys. 1997, 107, 3032; Reed, A. E.; Weinhold, F.; J. Chem. Phys. 1985, 83, 1736; Reed, A. E.; Curtiss, L. A.; Weinhold, F.; Chem. Rev. 1988, 88 , 899.

35. Glendening, E. D.; Badenhoop, J. K.; Reed, A. E.; Carpenter, J. E.; Weinhold, F.; NBO4.M; NBO Analysis Programs; University of Wisconsin, USA, 1999.

Received: September 18, 2009 Web Release Date: April 15, 2010

FAPESP helped in meeting the publication costs of this article. 


\section{Nitric Oxide as an Activation Agent for Nucleophilic Attack in trans $-\left[\mathrm{Ru}(\mathrm{NO})\left(\mathrm{NH}_{3}\right)_{4}\left\{\mathrm{P}(\mathrm{OEt})_{3}\right\}\right]\left(\mathrm{PF}_{6}\right)_{3}$}

\section{Gustavo Metzker, ${ }^{a}$ José C. Toledo Jr., ${ }^{b}$ Francisco C. A. Lima, ${ }^{c}$ Alvicler Magalhães, ${ }^{d}$ Daniel R. Cardoso ${ }^{a}$ and Douglas W. Franco $* a$}

aInstituto de Química de São Carlos, Universidade de São Paulo, Av. Trabalhador Sãocarlense 400, 13560-970 São Carlos-SP, Brazil

${ }^{b}$ Departamento de Química, Universidade Federal do ABC, Rua Santa Adélia 166, 09210-170 Santo André-SP, Brazil

${ }^{c}$ Centro de Ciências da Natureza, Coordenação de Química, Universidade Estadual do Piauí, Rua João Cabral, 2231, 64002-150 Teresina-PI, Brazil

${ }^{d}$ Instituto de Química, Universidade Estadual de Campinas, Cidade Universitária Zeferino Vaz, 13083-970 Campinas-SP, Brazil

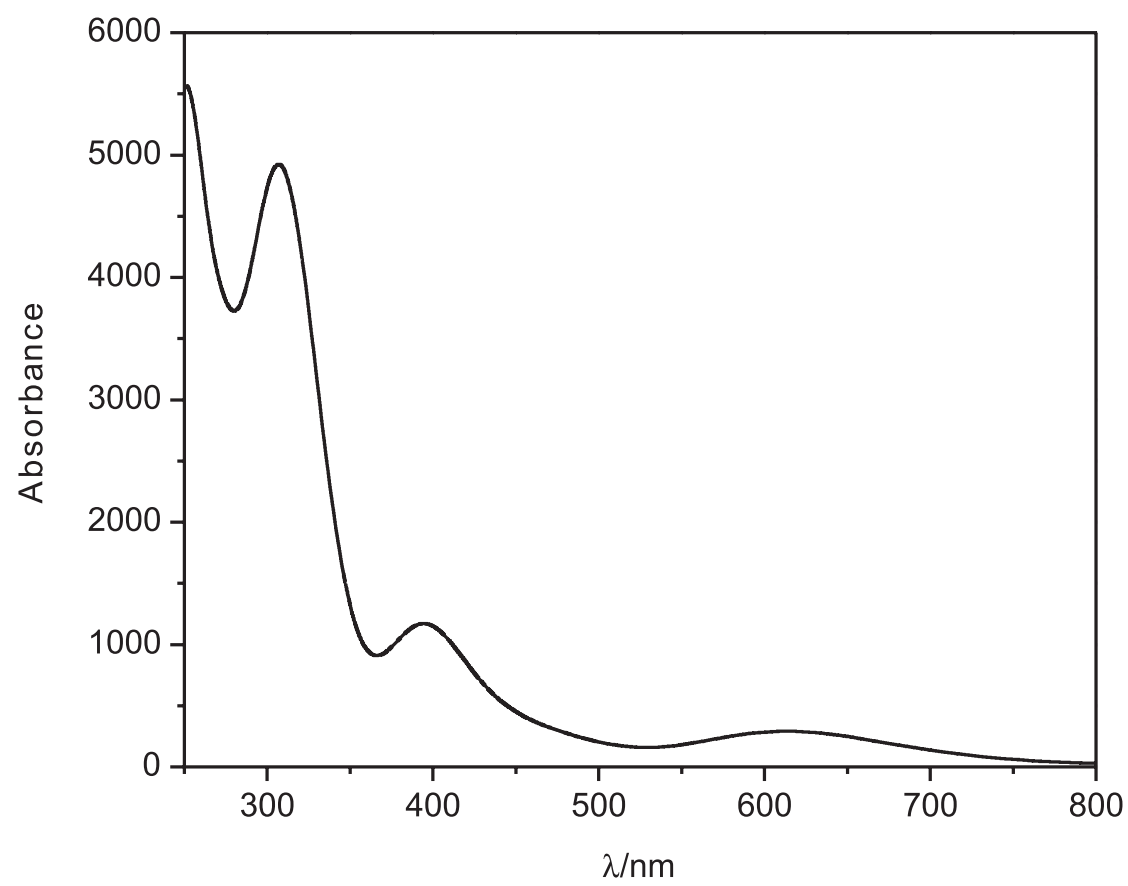

Figure S1. Simulated UV-Vis spectrum for the trans-[Ru(NO) $\left.\left(\mathrm{NH}_{3}\right)_{4}\left\{\mathrm{P}(\mathrm{OH})(\mathrm{OEt})_{2}\right\}\right]^{3+}$ complex using TD-DFT. Solvent: water. 